\title{
COMMERCIAL BONDS AS AN SOURCE OF FINANCING THE ACTIVITIES
} OF RUSSIAN ENTERPRISES

\author{
Prof. DSc. Alena Stupina ${ }^{1,2,3}$ \\ MS. Vladimir Petrov ${ }^{1}$ \\ Assoc. Prof. Roman Kuzmich ${ }^{1}$ \\ Assoc. Prof. Natalia Dzhioeva ${ }^{1}$ \\ Assoc. Prof. Irina Ruiga ${ }^{1}$ \\ ${ }^{1}$ Siberian Federal University, Russia \\ ${ }^{2}$ Reshetnev Siberian State University of Science and Technology, Russia \\ ${ }^{3}$ Krasnoyarsk State Agrarian University, Russia
}

\begin{abstract}
The relevance of the study is due to the fact that in conditions of debt load, the attraction of new bank loans by enterprises is unlikely, and may worsen the financial condition of the organization. Therefore, a bond loan is becoming a more popular and less risky alternative for enterprises. In this regard, this article is aimed at disclosing the features and technology of issuing commercial bonds, studying the dynamics of the Russian corporate bond market for 2014-2017, and justifying the attractiveness of this financial instrument. The main approach of this paper is a comparative approach that allows comprehensively justifying the popularity of the bond issue as a source of funding, based on statistical data. The paper reveals the peculiarities of the organization of a bond loan, reveals development trends and substantiates the attractiveness of this financial instrument based on a comparison of bond borrowing and bank lending, as well as on the basis of comparing the yield of commercial securities and bank deposits. The materials of the paper are practical value for organizations (limited liability companies, joint-stock companies) that plan to issue their own commercial bonds, as well as organizations and individuals who plan to make investments.
\end{abstract}

Keywords: bonds, commercial bonds, coupon, issuer, corporate bond market.

\section{INTRODUCTION}

Enterprises, whose capital structure is dominated by borrowed funds, are most exposed to the risk of declining solvency and deterioration of financial stability when attracting new loans. In such conditions, attracting new borrowed resources for various purposes (replenishment of working capital, financing projects) by means of a bank loan, as in most cases organizations do, can prove unprofitable and worsen financial condition. But in addition to bank loans, there are other sources of capital. The most popular of them in Russia is now becoming a bond loan.

Bond loan is one of the forms of borrowing, which is the issuance of securities (bonds) by the issuer (borrower), and the lenders are the buyers of these bonds (investors). In contrast to a bank loan with a bond loan, the borrower, together with the issuer, 
determines the conditions and parameters of the loan, which will be simultaneously beneficial for the enterprise and for investors. There are different types of bonds, but this paper discusses corporate (commercial) bonds that organizations can issue (joint stock companies, limited liability companies).

The aim of the paper is to reveal the features and technology of organizing the issuance of commercial bonds, to identify trends in the Russian corporate bond market, as well as to justify the attractiveness and popularity of this financial instrument.

The practical value of the study is the possibility of using the material to study the features of the organization of the issue of bonds for those companies that plan to use this source of funding, as well as when deciding on the choice of source of borrowed resources.

The theme of the paper is new and stands at the stage of popularization. Therefore, this problem has not been studied in sufficient detail yet, but it is worth noting the already existing works of such authors as Alekseeva I.A., Makarova E.V., Igonina L.L., Isaev M.V. Studies of the Russian commercial bond market were carried out, and some features of the bond issue were considered in their works.

\section{METHODS AND MATERIALS}

To substantiate the attractiveness and popularity of a bond loan, paper considers a comparison of this financial instrument with a bank loan / deposit based on a comparative approach. The approach involves the comparison of the object of study with a counterpart in certain parameters. On the one hand, in the paper this parameter will be the cost level of raising a loan, represented by the interest rate / coupon; on the other hand, another comparison parameter will be the yield of commercial bonds and bank deposits for investors, also represented by interest rates.

A bond is an issuance debt security that fixes the right of its holder to receive from the issuer at a certain time its nominal value and a fixed percentage of this value [1].

Bonds have the following features:

- they are not titles of ownership of the issuer's property, as opposed to shares, this is a loan certificate;

- they have a final maturity date, unlike shares;

- they have seniority to shares in the payment of interest and in the satisfaction of other obligations (for example, during the liquidation of the organization);

- bond's issuers are borrowers, debtors. Investors are creditors of the issuer.

The organization of a bond loan is a difficult process, which includes the stages of preparation, allocation and servicing of a loan (Figure 1) [6].

The first stage includes: searching and conducting business meetings of the issuer with potential investors, at which the issuer makes a presentation, his activities, and financial condition. Following the meeting, investors make a decision on investing the issuer. In this case, potential investors are clients (consumers) of the company's products. Further, the issuer on his web page creates a special section for investors, in which information on the issue of bonds is posted. Then the final approval of the allocation of the issuer's bonds, the terms and parameters of the issue, which are prescribed in the Concept of a bond loan, is taken. 
The second stage includes: conclusion of an agreement between the issuer and the National Settlement Depository (NSD) (on the creation of the issuing account, on the provision of services for the storage and transfer of funds from the issuer's issuing account to the investors' depot accounts); registration of the bond issue with NSD; installation of special software by the issuer for electronic document circulation with NSD; conclusion of contracts for the sale of bonds between the issuer and investors; allocation of bonds (transfer of a bond certificate for storage at NSD and transfer of bonds to investors' depot accounts).

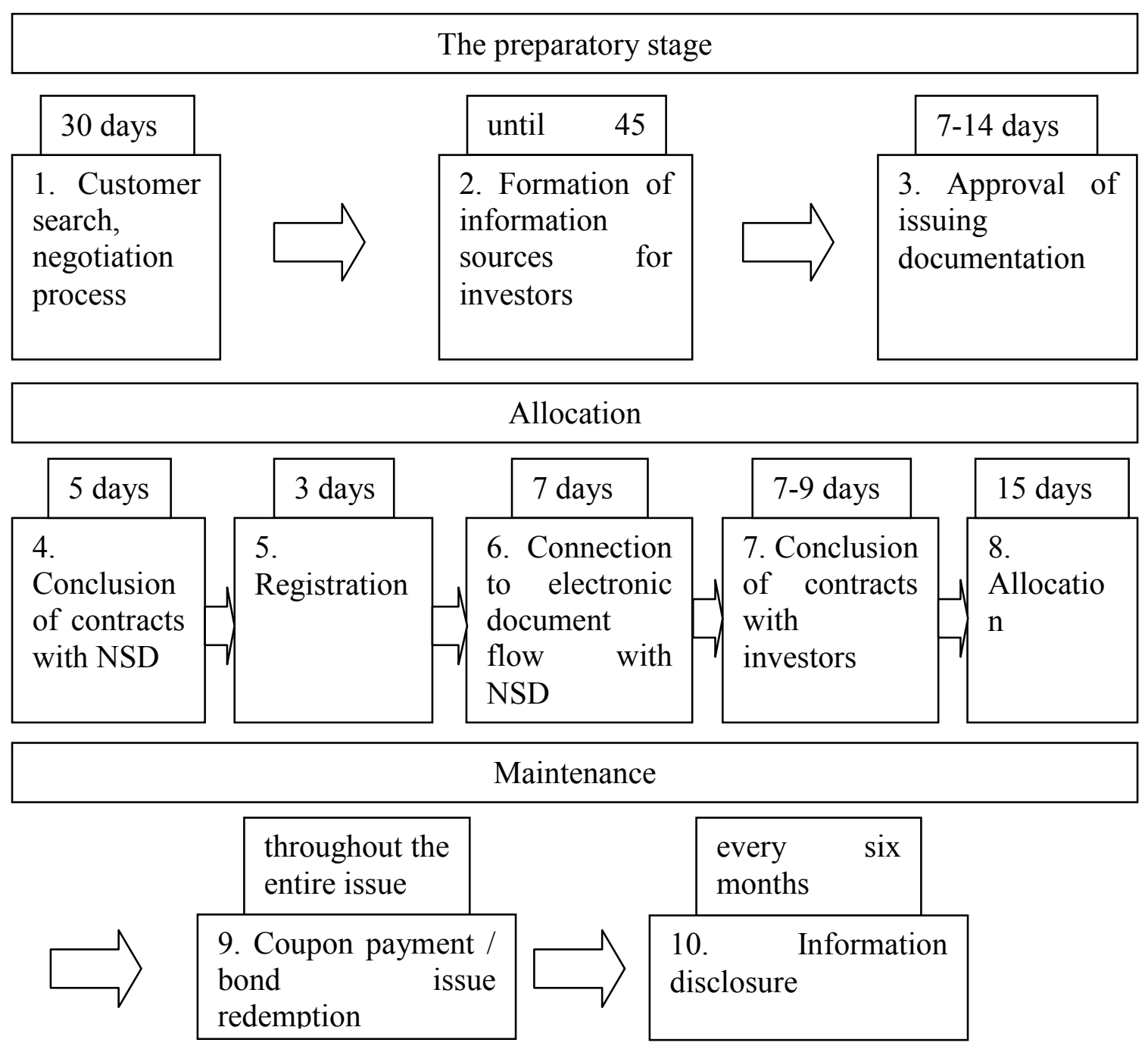

Figure 1 - Bond Loan Scheme

The third stage includes: making coupon payments to investors in accordance with the terms of the issue and publishing messages on the issuer's website about carrying out coupon payments and redeeming the face value of the bonds at the end of the circulation period.

Preparation and allocation of a bond involves the corresponding costs, which consist of a fee for registering the issue with NSD (400 thousand rubles), underwriter's 
remuneration for organizing the issue $(0.1-0.2 \%$ of the issue volume at par) and NSD for providing services on allocation and maintenance of securities, as well as other expenses for paperwork and consulting services. On average, the cost of organizing emissions is $0.1-0.3 \%$ of the total volume of emissions.

\section{RESULTS}

Corporate bonds, as a form of borrowing, have their own advantages and disadvantages, which must be considered when choosing this financial instrument. The main clear advantage over other forms of borrowing, including before a bank loan, is the low cost of the loan (low interest rate), which is beneficial to businesses. Lack of bank margin makes debt financing cheaper than lending. Also, interest rates on bonds decrease as the borrower's credit history is formed. Comparison of interest rates on bank loans and coupons on bonds in Russia is presented in Table 1, as well as in Figure 2 [4], [7].

Also, if bonds are considered from the point of view of investment, then investments in the securities of an organization will be more profitable than, for example, a similar bank deposit (Table 2 and Figure 3) [4], [7]. Moreover, in recent years, deposit rates tend to decline.

Table 1 - Comparison of average interest rates on bank loans and coupons on commercial bonds

\begin{tabular}{|c|c|c|c|c|}
\hline Indicator & 2015 & 2016 & 2017 & $\begin{array}{c}\text { I, II quarter } \\
\text { of 2018 }\end{array}$ \\
\hline \hline Credit, \% & 14.9 & 13 & 10.6 & 8.8 \\
\hline Bonds, \% & 13.7 & 10.5 & 9.3 & 8.3 \\
\hline Deviation, percentage points & 1.2 & 2.5 & 1.3 & 0.5 \\
\hline
\end{tabular}

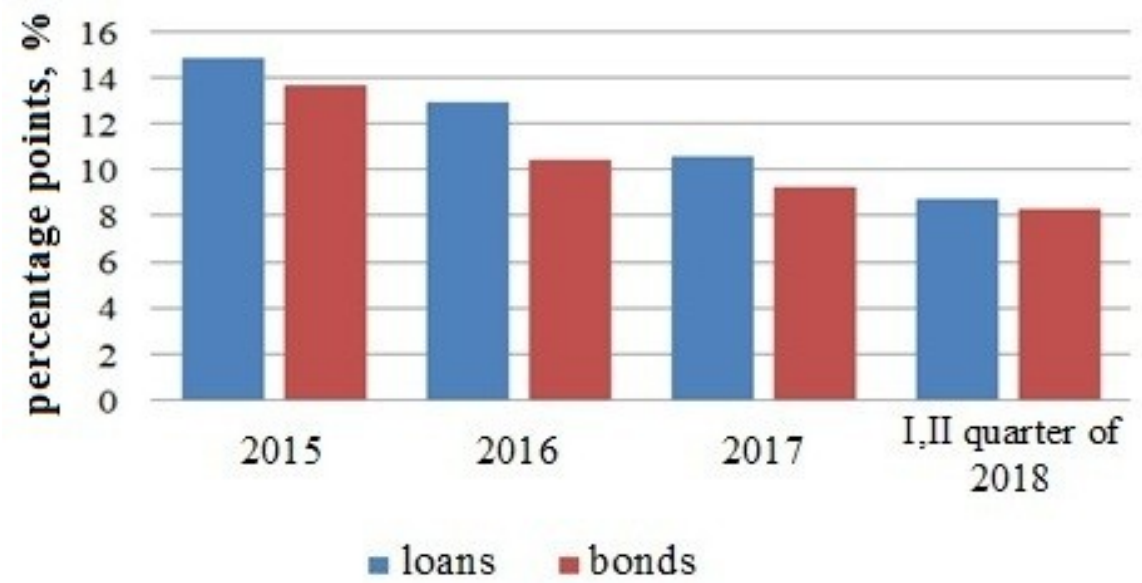

Figure 2 - Average interest rates on loans and corporate bonds in Russia for 2015 - I quarter of 2018 
Table 2 - Comparison of average interest rates on bank deposits and coupons on commercial bonds

\begin{tabular}{|c|c|c|c|c|}
\hline Indicator & 2015 & 2016 & 2017 & $\begin{array}{c}\text { I, II quarter of } \\
2018\end{array}$ \\
\hline \hline Deposit, \% & 11.4 & 9.3 & 7.8 & 5.9 \\
\hline Bonds, \% & 13.7 & 10.5 & 9.3 & 8.3 \\
\hline Deviation, percentage points & -2.3 & -1.2 & -1.5 & -2.4 \\
\hline
\end{tabular}

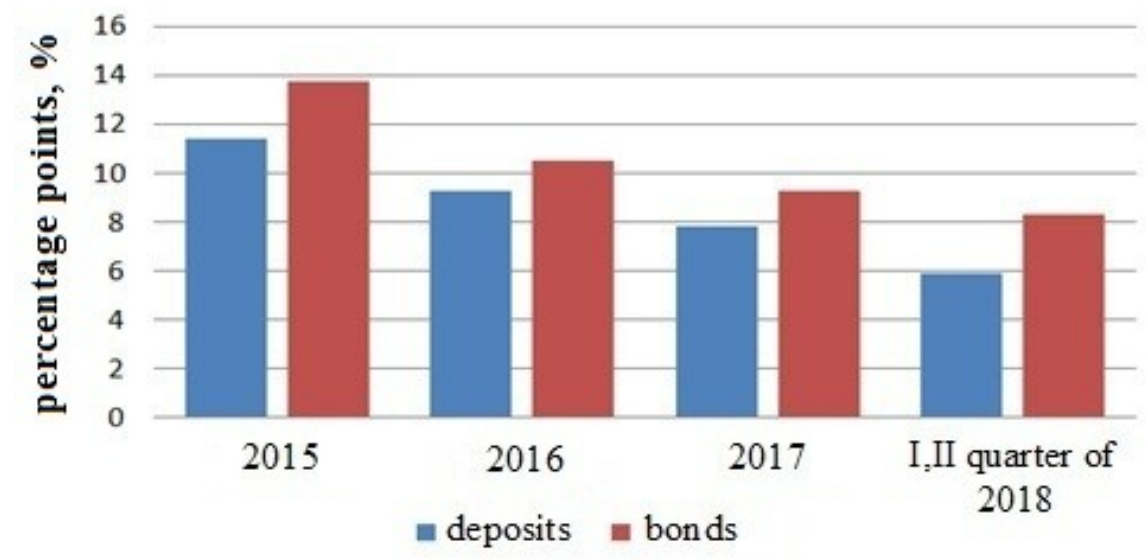

Figure 3 - Average interest rates on deposits and corporate bonds in Russia for 2015 - I quarter of 2018

Advantages of commercial bonds:

- ability to manage your own debt. Debt obligations can be formed in such way as to take into account the interests and needs of the borrowing company. Transactions with own debt securities allows for flexible debt management.

- diversification of sources of funds. Attracting borrowed funds through bonds, the borrower receives a loan from a large number of investors, which can be both ordinary banks and insurance companies, pension funds, financial, brokerage, investment companies, individuals, etc.

- formation of public credit history. As investors see that the borrower fulfills his obligations timely and in full, their confidence in the company increases and their willingness to lend to it.

- the possibility of increasing borrowing. The capacity of the debt market is higher than the lending capacity of banks due to a larger number of lenders. Qualitative and quantitative growth of the market as a whole allows increasing the amount of credit.

- no need to provide collateral. In the case of attracting borrowed funds by issuing bonds, there is no need (as in the case of a bank loan) to provide collateral. 


\section{Disadvantages:}

- the need for public disclosure of information about the issuer. On the one hand, the company makes information more open (including for competitors), and on the other hand, it requires additional costs associated with information disclosure.

- the organization of the bond issue provides for the corresponding costs (remuneration of the underwriter, registration of the issue, NSD services for storage and for settlement, consulting, preparation of documentation, etc.).

- a longer period for the preparation of borrowing in comparison with the conventional loan (this is due to the procedures for state registration of the issue of bonds, search and work with potential investors, preparation of the initial allocation of the loan).

In addition to the features and advantages of this loan type for a borrower-enterprise, the attractiveness of a financing source is determined by the fact that in recent years the domestic market of corporate bonds has been actively developing. The dynamics of development indicators of the corporate bond market in Russia is presented in Figure 4 [2].

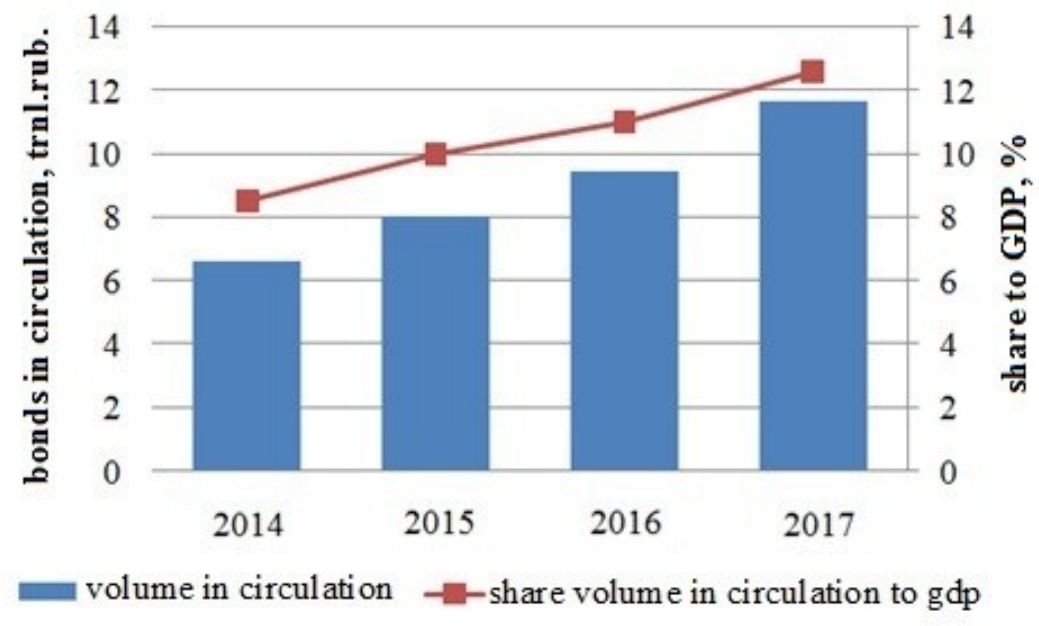

Figure 4 - Dynamics of the value of commercial bonds in circulation and their share in GDP for 2014-2017

For 2014-2017 the volume of the corporate bond market in Russia increased almost two times: from 6.62 to 11.7 trillion rubles, and as compared with GDP, from 8.5 to $12.6 \%$.

Despite the observed annual growth in the volume of the Russian bond market, in 2014 there was a decline in the growth rate of allocation volumes by $34 \%$ [2]. This can be explained by the fact that at the end of 2014 the devaluation of the ruble occurred and the increase in the key rate of the Central Bank to $17 \%$. As a result, there was a decrease in investment in ruble-denominated corporate bonds.

But in 2015, the situation began to change again for the better: a gradual reduction in the key rate, growth in bank lending, and external financing - all this allowed an increase in the volume of emissions. 
In 2016 the Central Bank continued to reduce the key rate (up to 10\%), inflation decreased (5.4\%) [8]. These factors also had a positive effect on the growth in the volumes of the primary allocation of bonds ( 2.36 trillion rubles at the end of the year).

In 2017, the bond market continued to grow: from 9.44 to 11.7 trillion rubles. Low inflation $(2.5 \%)$, a reduction in the key rate to $7.75 \%$ by the end of the year, a stable ruble exchange rate - all of this had a positive effect on the securities market as a whole [8].

But the concentration of corporate bond issues remains high: by the end of 2016, the ten largest issuers accounted for $50 \%$ of the total issue amount [3]. And the majority of these issuers are state-owned companies.

Analyzing the sectoral structure of the issuance of corporate bonds in Russia, it can be said that the key segments are banks, the oil and gas industry, and financial institutions. This structure is presented in Figure 5 [2].

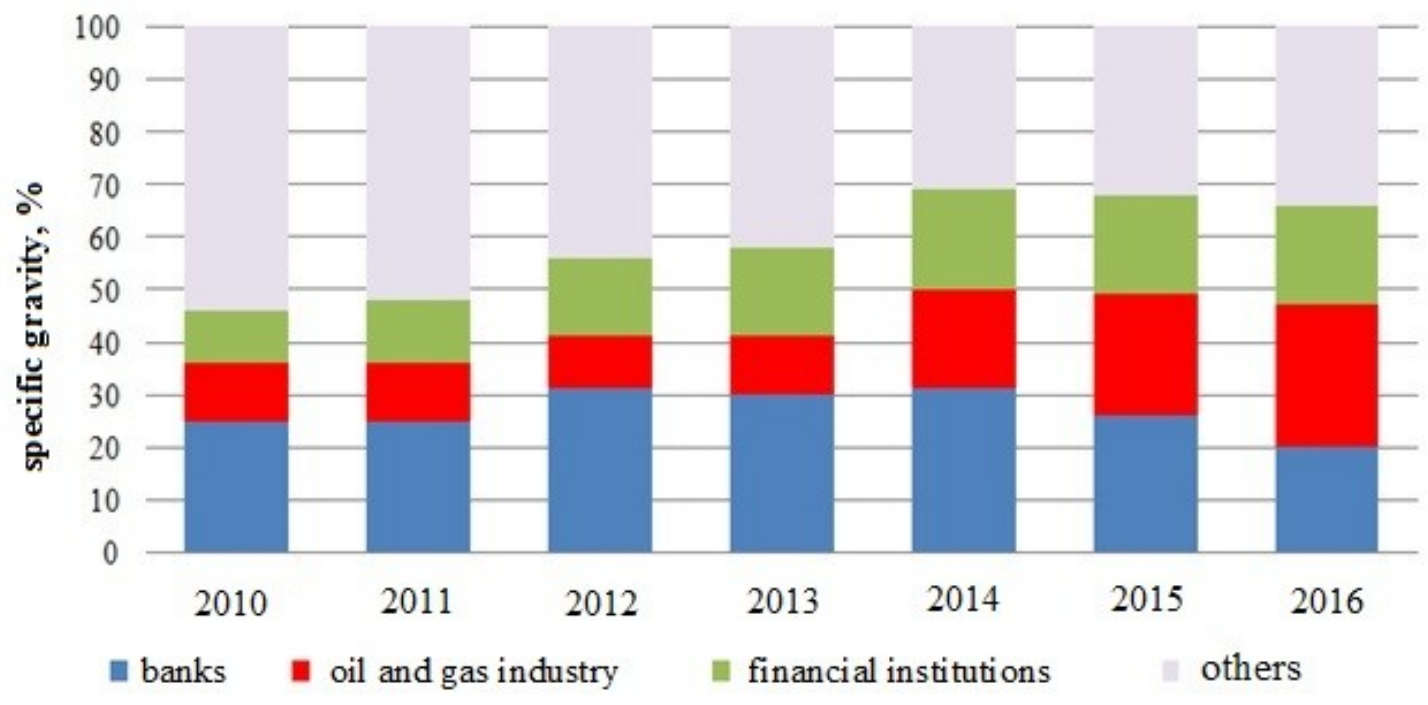

Figure 5 - Sectoral structure of corporate bond issues in 2010-2016

In 2010-2014 there is an increase in bond issues among banks and financial institutions, but starting in 2015, due to limited access of Russian issuers to sources of external financing, there is a decline in the share of the banking sector in favor of growth in the oil and gas industry and other industries.

Bond loan is also becoming popular due to the fact that the term of the loan is higher than the deposit. At the same time, there has recently been a tendency in the bond market to lengthen borrowing terms: the maturity of $40 \%$ of bond issues in 2016 was 510 years [2].

Also at the state level conditions are created to stimulate the emission activity of Russian enterprises. For example, the decision made by the State Duma not to charge ruble bonds issued from January 1, 2017 by personal income tax (exceptions are cases when coupon income exceeds the key rate), insurance of individual investment accounts (made by the Duma on June 21, 2017) [3]. 
All this suggests that the demand for corporate bonds as a tool for investing and attracting investments by the corporate sector of the economy in Russia will only grow.

\section{CONCLUSION}

Bond loan is a fairly good and effective alternative to a bank loan. This fact proves the growing demand and volume of the bond market, namely commercial bonds in Russia. The emergence of large companies with excessive liquidity, the creation of incentive laws, the improvement of technology and the organization of the bonds issue - all these factors contributed to the development of the bond market.

Nevertheless, there are disadvantages of this financing instrument compared to a bank loan, the most significant of which are the complex and lengthy process of issuing, the search for potential investors and the mandatory disclosure of information. Of course, these disadvantages are offset by the benefits of the bond loan.

Bond loan is an attractive option for financing projects of enterprises, because it is possible to design the issue of bonds for the indicators and conditions of the project. At the same time this tool is cheaper than attracting most bank loans (from the issuer) and is more profitable than deposits on deposits (from investors). Also, the bond loan in this case does not require additional security.

Therefore, based on all of the above, it can be said that the bond loan is a good, attractive, efficient and promising source of attracting borrowed funds, which will continue to develop in the long term.

\section{REFERENCES}

[1] Mirkin Ya.M., Losev S. V., Rubtsov B. B., Dobashina I. V., Vorobyova Z. A., Guidelines for the organization of the issue and circulation of corporate bonds, Development of Underwriting in Russia, Russia, 2004, 385 p. (in Russian).

[2] Alekseeva I.A., Makarova E. V., Russian corporate bond market: trends and development prospects, Bulletin of the Baikal State University, vol. 3, pp 389-400, 2017 (in Russian).

[3] Corporate bonds 2017: market, profitability and taxation [electronic resource]: Industrial development. - Access mode: https://promdevelop.ru/korporativnyeobligatsii/ (in Russian).

[4] Analysis of bonds [electronic resource]: the Rusbond project. - Access mode: http://www.rusbonds.ru (in Russian).

[5] Practice of issuing commercial bonds [electronic resource]: presentation of the Bank of Russia. - Access mode: https://www.cbr.ru (in Russian).

[6] Information disclosure to investors [electronic resource]: Butcher site. - Access mode: http: //myasnichiy24.rf/ (in Russian).

[7] Interest rates and the structure of loans and deposits by urgency [electronic resource]: the site of the Central Bank of the Russian Federation. - Access mode: https://www.cbr.ru/ (in Russian).

[8] Inflation in Russia [electronic resource]. - Access mode: http: // level- inflation.rf (in Russian). 